\title{
Bad Governance dan Keruntuhan Ekonomi di Indonesia
}

\author{
Alexander Irwan, Ph.D
}

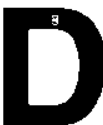

i bawah pemerintahan Soeharto, Indonesia merupakan sebuah negeri miskin, seperti banyak negeri miskin lainnya di dunia ini, yang berupaya mengejar ketertinggalannya dengan negeri-negeri kaya melalui pembangunan ekonomi. Karena itu, ketika indikator-indikator keberhasilan pembangunan ekonomi menunjukkan prestasi yang mengesankan, le- gitimasi pemerintahan Soeharto di mata masyarakat dalam dan luar negeri menjadi kuat. Sebaliknya, ketika yang muncul ke permukaan adalah indikator-indikator ekonomi yang menunjukkan jatuhnya perekonomian Indonesia, seperti yang terlihat dalam Tabel 1, legitimasi pemerintahan Soeharto, seperti yang sedang terjadi di awal tahun 1998 ini, merosot drastis.

Tabel 1 Economic growth and GNP per capita

\begin{tabular}{|c|c|c|}
\hline Year & Growth (\%) & GNP per capita US\$ \\
\hline 1990 & 7.2 & 561.3 \\
\hline 1991 & 6.9 & 595.0 \\
\hline 1992 & 6.3 & 649.7 \\
\hline 1993 & 7.3 & 842.0 \\
\hline 1994 & 7.5 & 886.0 \\
\hline 1995 & 8.2 & 978.0 \\
\hline 1996 & 8.0 & $1,155.0$ \\
\hline 1997 & $4.7^{*}$ & $1,089.0$ \\
\hline 1998 & $0.0^{* *}$ & $610.0^{\star \star *}$ \\
\hline
\end{tabular}

* Temporary figure

** Projected growth, State Budget Plan 1998/1999.

*** Projection by the State Minister of national Development -Chief of Bappenas Ginanjar Kartasasmita, presented in front of the Commision VIII of the People's Representative on February 16, 1988.

Source: Financial Notes of the State Budget Plan 1994/1995 and 1997/1998; Bank Indonesia The President's Accountability Adress to the Poeple's Consultative Assembly, 1998; Bisnis Indonesia's Center of Documentation; Data Consult. 
Selama tiga puluh tahun di awal pemerintahan Soeharto, dari tahun 1967 sampai 1997 , tampak dengan jelas bahwa perekonomian Indonesia semakin erat terkait dengan perekonomian global. Semakin mendekati akhir abad ke 20, pembangunan ekonomi Indonesia semakin mengandalkan modal asing, baik yang masuk dalam bentuk hutang, penanaman modal langsung, modal porto folio yang masuk lewat pasar modal, maupun modal asing yang masuk ke Indonesia lewat pasar uang karena ingin memanfaatkan tingginya tingkat suku bunga di Indonesia. Sektor industri Indonesia juga semakin mengandalkan barang-barang impor (baik bahan mentah, setengah jadi, maupun bahan pendukung), dan menjajakan produk-produknya di pasar ekspor manca negara. Bahkan Indonesia juga sudah menyatakan diri bergabung dengan upaya untuk mendorong liberalisasi di tingkat regional (AFTA) dan global (APEC dan WTO).

Semakin terkaitnya perekonomian Indonesia dengan perekonomian global ternyata tidak diikuti dengan kedisiplinan dan transparansi menajemen ekonomi makro. Sejak dari tahun 1967 sampai 1997, untuk mempertahankan legitimasinya pemerintahan Soeharto mengandalkan indikator-indikator ekonomi yang menunjukkan keberhasilan pembangunan. Karena adanya kepentingan politik tersebut, indikator-indikator ekonomi vital menjadi tidak lagi mencerminkan realitas yang sebenarnya. Padahal angka-angka indikator ekonomi tersebut digunakan sebagai panduan dalam menentukan kebijakan-kebijakan ekonomi, termasuk kebijakan yang berhubungan langsung dengan kaitan perekonomian Indonesia dan perekonomian global.

Bad governance dalam bentuk rekayasa indikator-indikator ekonomi menyebabkan diambilnya kebijakan-kebijakan ekonomi yang kurang tepat, dan terbukti menyebabkan lemahnya daya tahan perekonomian Indonesia dalam menghadapi krisis moneter sekarang ini. Dilihat dari tingkat penurunan nilai rupah, lihat Tabel 2 , kinerja perekonomian Indonesia adalah paling parah di Asia. Sementara pada awal bulan

Tabel 2

Tingkat penurunan nilai mata uang Asia, 2 Januari 1997 - Februari 1998

\begin{tabular}{|l|l|}
\hline \multicolumn{1}{|c|}{ Mata uang } & \multicolumn{1}{c|}{ Tingkat (\%) } \\
\hline $\begin{array}{l}\text { Indonesia (rupiah) } \\
\text { US } \$ 1=\text { Rp. 9.000 } \\
\text { US } 1=\text { Rp. 10.000 }\end{array}$ & 281 \\
\hline Thaliand (bath) & 323 \\
\hline Malaysia (ringit) & 714 \\
\hline The Philippines (peso) & 67 \\
\hline Singapore (dollar) & 26 \\
\hline
\end{tabular}

Sumber: Subiantoro (1998). 
Maret 1998 perekonomian Thailand (yang sekarang berada di bawah PM baru Chuan Leekpai) dan perekonomian Korea Selatan (di bawah kepemimpinan presiden baru Kim Dae Jung) sudah mulai menunjukkan titik balik menuju ke recovery, perekonomian Indonesia (di bawah kepemimpinan presiden lama yang baru saja terpilih kembali, Soeharto) menjadi faktor penghambat pulihnya perekonomian negara-negara Asia lainnya.

Artikel. ini membahas bagaimana bad governance dalam bentuk penentuan angka inflasi sangat besar perannya dalam menciptakan kelemahan struktur perekonomian Indonesia. Diharapkan bahwa analisa ini dapat membantu menemukan solusi yang akan mampu mengangkat kembali kinerja perekonomian Indonesia.

\section{Indikator Kesuksesan \\ Pembangunan Ekonomi Indonesia}

Selama tiga puluh tahun, pemerintahan Soeharto menggunakan berbagai indikator ekonomi untuk mengatur keberhasilan pembangunan. Dua indikator yang penting adalah jumlah penduduk Indonesia yang ada di bawah garis kemiskinan, dan angka inflasi yang dipertahankan di bawah dua digit. Pentingnya dua indikator tersebut dalam penciptaan legitimasi politik mendorong pemerintahan menciptakan formula penghitungan yang menghasilkan angka-angka yang tidak mencerminkan realitas yang sebenarnya.

Seperti yang diungkapkan oleh Basri (1997), dalam Pidato Presiden pada tahun 1996 dinyatakan bahwa terdapat 22 juta penduduk Indonesia yang hidup di bawah garis kemiskinan. Setahun sebelumnya, data SUSENAS menunjukkan bahwa pada tahun 1995 jumlah orang miskin di lindonesia tercatat sebesar 25 juta. Jadi dalam waktu satu tahun sejumlah tiga juta orang berhasil "dientaskan" dari kemiskinan, sebuah prestasi yang mengesankan. Untuk menghitung jumlah penduduk miskin, ditarik garis kemiskinan pada kisaran pendapatan sekitar Rp 900 per hari untuk penduduk kota dan $R p 600$ per hari untuk penduduk desa. Sulit untuk membayangkan bagaimana seseorang bisa mencukupi kebutuhan sandang, pangan, dan papan, apalagi pendidikan dengan tingkat pendapatan tersebut.

Angka jumlah penduduk Indonesia yang hidup di bawah garis kemiskinan tersebut tidak mencerminkan realitas yang ada. Buktinya, menurut Basri, formula yang dipakai menghitung jumlah penduduk miskin di Indonesia tersebut menghasilkan angka yang fantastis mengenai jumlah penduduk Indonesia yang hidup nyaris di bawah garis kemiskinan. Bila garis kemiskinan tersebut dinaikan seratus rupiah menjadi Rp. 1.000 per hari, jumlah orang miskin akan melompat drastis dari 22 juta menjadi 77 juta. Apalagi bila garis kemiskinan dinaikkan menjadi Rp. 2.000, sebuah pendapatan harian yang bisa dipastikan belum juga bisa dipakai untuk memenuhi kebutuhan hidup sehari-hari, jumlah penduduk miskin di Indonesia meningkat lebih fantastis lagi, yaitu ke bilangan 153 juta penduduk. Formula penghitungan diciptakan untuk menghasilkan angka yang bisa meningkatkan legitimasi politik pemerintah.

Nasib formula penghitungan angka inflasi bisa dipastikan mengalami nasib yang sama, dan dalam jangka panjang membawa konsekuensi yang sangat dahsyat terhadap perekonomian nasional Indonesia. Angka inflasi sangat penting karena bukan hanya merupakan sebuah indikator keberhasilan pembangunan ekonomi, tapi juga sangat mempengaruhi sebuah indikator keberhasilan pembangunan ekonomi lainnya, yaitu GNP per kapita. Tabel 3 menunjukkan bahwa paling tidak sejak tahun 1987 , pemerintah Soeharto berhasil menekan in- 
Topik: Bad Governance dan Keruntuhan Ekonomi di Indonesia, Alexander Irwan, Ph.D

flasi sehingga tidak pernah menembus angka dua digit. Alasan kenapa angka inflasi perlu ditekan di bawah dua digit adalah karena tingginya tingkat inflasi akan menurunkan tingkat hidup rakyat Indonesia.

Tapi angka inflasi bukan hanya sekedar merupakan indikator tingkat kesejahteraan. Lebih dari itu, angka inflasi sangat penting artinya dalam penentuan tingkat depresi ketika nilai rupiah masih menggunakan sistem managed-float, sejak tahun 1986 sampai agustus 1997. Dalam periode itu, depresi nilai rupiah ditentukan oleh perbedaan tingkat inflasi di Indonesia dengan tingkat inflasi di AS. Bila tingkat inflasi di Indonesia adalah $8,5 \%$, maka rupiah pada tahun tersebut didepresikan sebesar 6\%.

Yang menjadi masalah adalah ketika formula yang dipakai oleh pernerintah un- tuk menghitung inflasi menghasilkan figur yang tidak mencerminkan angka riil inflasi. Apabila angka inflasi resmi di Indonesia pada bulan Januari 1998 sebesar $6.88 \%$, di tengah melonjak tajamnya harga barangbarang akibat melemahnya nilai rupiah dan menurunnya suplai, dianggap tidak mencerminkan komoditi riil, berapa sebetulnya tingkat inflasi yang riil terjadi? Meskipun telah dianggap konservatif, tingkat inflasi dua kali lipat dari versi resmi pemerintah, yaitu $13,76 \%$, dianggap bisa diterima. Apabila asumsi bahwa angka inflasi riil sebetulnya dua kali lipat dari angka inflasi resmi, dan hal itu sudah berlangsung selama kurang lebih dua puluh tahun, bisa dipastikan bahwa tingkat overvalue nilai rupiah adalah sangat tinggi.

Berapa sebetulnya nilai riil rupiah sebelum diambangkan (free float) pada perte-

\section{Tabel 3. Perkiraan nilai riil rupiah terhadap US\$}

\begin{tabular}{|c|c|c|c|c|}
\hline Tahun & $\begin{array}{c}\text { Nilai resmi rupiah } \\
\text { (Rp.) }\end{array}$ & Depresiasi (\%) & $\begin{array}{c}\text { Tingkat Inflasi } \\
\text { resmi (\%) }\end{array}$ & $\begin{array}{c}\text { Perkiraan nilai riil } \\
\text { rupiah (Rp.) }\end{array}$ \\
\hline 1987 & 1.643 & & 8,55 & 1.862 \\
\hline 1988 & 1.722 & 4,8 & 7,45 & 1.862 \\
\hline 1989 & 1.800 & 4,5 & 6,80 & 2.085 \\
\hline 1990 & 1.901 & 5,6 & 9,53 & 2.343 \\
\hline 1991 & 1.992 & 4,7 & 9,52 & 2.677 \\
\hline 1992 & 2.062 & 3,5 & 4,94 & 3.025 \\
\hline 1993 & 2.110 & 2,3 & 9,57 & 3.244 \\
\hline 1994 & 2.200 & 4,2 & 9,24 & 3.690 \\
\hline 1995 & 2.308 & 4,9 & 8,64 & 4.213 \\
\hline 1996 & 2.383 & 3,2 & 6,47 & 4.711 \\
\hline
\end{tabular}

* Dihitung berdasarkan asumsi bahwa tingkat inflasi riil, adalah dua kali tingkat inflasi resmi.

Sumber: Bank Indonesia, Biro Pusat Statistik. 
ngahan tahun 1997 ini? Sulit untuk mendapatkan angka yang pasti. Yang bisa diusahakan adalah sebuah perkiraan. Berdasarkan asumsi bahwa nilai riil inflasi sejak tahun 1987 adalah dua kali lipat dari angka resmi yang dikeluarkan pemerintah, tingkat depresi rupiah yang diterapkan dari tahun selama periode 1987 - 1996 haruslah jauh lebih tinggi, yaitu sebesar angka depresiasi resmi (yang mencerminkan perbedaan tingkat inflasi di A.S. dibanding dengan tingkat inflasi resmi di Indonesia) ditambah dengan angka inlasi resmi tahun tersebut.

Dalam tabel 3 terlihat bahwa pada tahun 1996, ketika angka kurs resmi rupiah terhadap dolar AS adalah Rp. 2.383, nilai riil rupiah diperkirakan sebetulnya sudah mencapai Rp. 4.711. Perlu ditekankan bahwa perhitungan tersebut dimulai sejảk tahun 1987. Padahal untuk mendapatkan gambaran yang lebih tepat mengenai angka riil rupiah, perhitungan seharusnya dilakukan sejak awal tahun 1970-an. Devaluasi yang tajam pada tahun 1986 juga harus dihitung apakah langkah tersebut berhasil mengembalikan rupiah pada nilai riilnya pada waktu itu, atau tetap membiarkan rupiah overvalued.

Apabila perhitungan dilakukan mundur lima belas tahun lagi, yaitu dimulai pada awal tahun 1970-an, pasti nilai riil rupiah pada tahun 1996 tidak lagi Rp. 4.711, tapi lebih rendah lagi. Seberapa persis lebih rendahnya, memang hanya bisa ditebak. Mungkin angkanya mendekati Rp: 7.000 sampai Rp. 8.000. Itu mungkin sebabnya ancaman akan diterapkannya currency board system (CBS), yang akan mematok rupiah pada nilai antara Rp. 5.000 sampai Rp. 6.000 tidak berhasil menurunkan nilai rupiah ke tingkat tersebut. Bahkan sampai menjelang Sidang Umum MPR nilai rupiah tetap berkisar pada bilangan Rp. 8.000 , tidak di bilangan Rp. 5.000 atau Rp. 10.000,-
Sebelum membicarakan apa akibat dari perhitungan angka inflasi yang lebih rendah dari nilai riilnya, yang menyebabkan rupiah mengalami overvalue dalam jangka waktu yang sangat lama, perlu ditujukkan apa fungsi dari nilai rupiah yang overvalued tersebut terhadap legitimasi pemerintah Soeharto. Dalam Tabel 1 tampak bahwa GNP per kapita Indonesia pada 1996 adalah US\$1.155, pada nilai tukar rupiah Rp. 2.383 per US\$, lihat Tabel 3. Apabila nilai inflasi sejak awal dihitung sehingga mencerminkan nilai riilnya, dan dengan demikian nilai tukar resmi pada tahun 1996 adalah Rp. 4.711, GNP per kapita Indonesia pada tahun 1996 akan masih cukup jauh dari bilangan US\$1.000. Diperkirakan nilainya tidak akan jauh dari perkiraan Ketua Bappenas Ginanjar Kartasasmita untuk GNP per kapita Indonesia tahun 1998 sebesar US\$ 610. Apa yang terjadi dengan legitimasi pemerintah Soeharto bila pada tahun 1996 GNP per kapita Indonesia baru mencapai bilangan US\$ 600 , dan dengan demikian Indonesia tetap berada dalam kategori negara miskin? Jadi angka inflasi resmi yang jauh dari angka inflasi riil juga dipergunakan untuk mendongkrak nilai GNP per kapita Indonesia yang dihitung dalam sätuan dolar AS.

\section{Dimanjakan oleh impor murah}

Apabila memang betul bahwa tingkat overvalue dari nilai rupiah adalah sedemikian besar, menjadi masuk akal bahwa daya tahan perekonomian Indonesia terhadap depresi rupiah sangat lemah. Tingginya tingkat overvalue rupiah, membuat tahu dan tempe lebih murah kalau kedelainya diimpor daripada kalau ditanam di tanah air sendiri. Demikian juga dengan gula pasir. Sama ceritanya kenapa buah impor berhasil menggeser buah lokal. Daftarnya panjang sekali: dari mobil, barang elektronik, 
Topik: Bad Governance dan Keruntuhan Ekonomi di Indonesia, Alexander Irwan, Ph.D

susu, tekstil, sampai ke obat-obatan, komponen impornya sangat tinggi karena nilai rupiah yang overvalue membuat impor menjadi sangat murah. Apalagi karena produksi di dalam negeri diberati oleh tidak efisiennya birokrasi, adanya berbagai macam tata niaga, dan banyaknya pungutan yang legal maupun yang tidak legal, yang semuanya meningkatkan biaya produksi.

Apabila sejak awal tahun 1970an, atau mulai pertengahan tahun 1980an, yaitu ketika revenue dari minyak mulai merosot drastis, formula perhitungan angka inflasi yang digunakan oleh pemerintah menghasilkan angka inflasi yang riil, dan dengan demikian tingkat depresi rupiah terhadap dolar US juga lebih tinggi, ceritanya akan lain lagi. Karena nilai rupiah tidak overvalue, maka impor relatif menjadi mahal. Karena impor relatif mahal maka menjadi relatif lebih murah kalau memproduksi raw materials dan komponen di dalam negeri. Kandungan komponen impor-pun menjadi relatif jauh lebih rendah, dan daya tahan Indonesia dalam menghadapi krisis moneter sekarang ini akan jauh lebih kuat.

\section{Nilai rupiah sebaiknya stabil di tingkat berapa?}

Setelah dimanjakan oleh impor murah selama dua puluh tahun, perekonomian Indonesia tidak akan bisa lagi bertahan apabila nilai rupiah sekarang ini dibiarkan di tingkat nilai riilnya, yang menurut perkiraan adalah sekitar $R p .7 .000$ sampai $R p$. 8.000. Perusahaan-perusahaan besar tidak akan sangup bayar hutang mereka dalam dolar AS, industri tidak kuat mengimpor bahan mentah dan komponen, dan rakyat tidak kuat bertahan menghadapi tingkat inflasi yang sangat tinggi.

Menurut perhitungan yang selama ini beredar, nilai rupiah sebaiknya stabil pada tingkat Rp. 5.500. Tapi harus diingat bahwa menurut perkiraan artikel ini, pada tingkat nilai tukar Rp:5.500, nilai rupiah akan tetap overvalued. Pada tingkat nilai tukar sekitar Rp. 8.000 seperti sekarang inipun perusahaan-perusahaan Indonesia tidak bisa memanfaatkan situasi untuk menggenjot ekspor. Apalagi pada tingkat ini rupiah Rp. 5.500, sementara negara-negara tetangga di ASEAN semuanya juga mengalami depresiasi seperti yang terlihat dalam Tabel 2, yang membuat produk-produk mereka menjadi lebih kompetitif di pasar dunia. Apalagi kalau nanti Cina juga mendevaluasi mata uangnya. Bisa jadi daya saing produk-produk Asia Tenggara di pasar dunia yang meningkat karena adanya depresiasi yang diakibatkan krisis moneter sekarang ini menjadi hilang sama sekali karena sekali lagi tersaing oleh Cina.

Apalagi nilai rupiah stabil pada kisaran Rp. 5.500 supaya perusahaan-perusahaan besar (yang dimiliki oleh para konglomerat) bisa bayar hutang, industri bisa mengimpor bahan mentah dan komponen, dan rakyat tidak tercekik tingginya angka inflasi, stabilitas nilai rupiah pada tingkat $\mathrm{Rp} . \mathbf{5 . 5 0 0}$ tidak bisa dibiarkan berlaku lama. Setelah situasi agak membaik, nilai rupiah harus turun lagi mendekati nilai riilnya supaya barang-barang produk Indonesia kompetitif di pasar dunia dan Indonesia bisa mendatangkan devisa yang lebih banyak. Jadi sekarang betul-betul diperlukan koordinasi antara kebijakan fiskal dengan kebijakan sektor riil untuk bisa mengembangkan daya kompetisi produk-produk Indonesia. Jangan sampai pengalaman memanjakan sektor industri dengan impor murah terulang lagi.

Praktek pemulihan perekonomian Indonesia tentu saja tidak semudah karena adanya hambatan-hambatan eksternal dan internal. Pertama, adanya faktor Cina. Kekuatan ekonomi Cina merupakan faktor yang amat penting dalam keberhasilan pemulihan perekonomian-perekonomian di 
Asia Tenggara. Apabila Cina tidak bersedia berkorban secara ekonomi, dan dalam waktu dekat mendevaluasi mata uangnya (pada tahun 1992 Cina melakukan devaluasi sebesar $40 \%$ ), daya kompetisi perekonomian Asia Tenggara yang diperoleh karena melemahnya mata uang mereka akan terkikis.

Kedua, dalam menghadapi krisis ekonomi yang sangat parah ini, bersediakah pemerintahan Soeharto bertindak jujur dalam menghitung indikator-indikator ekonomi nasional. Apabila angka inflasi riilnya adalah $20 \%$, harus dikatakan $20 \%$, dan bukannya $7,5 \%$ atau $10 \%$. Apabila angka inflasi tinggi, legitimasi bisa diperoleh dari tempat lain, misalnya dengan memberantas habis korupsi, kolusi, dan nepotisme. Dan juga dengan menolak tekanan dari IMF untuk mengurangi subsidi BBM dan barang-ba- rang kebutuhan pokok lainnya, yang bisa dipastikan bila dituruti akan semakin memerosotkan tingkat kesejahteraan rakyat banyak. Apakah pemerintahan Indonesia akan bersedia melakukan hal itu, sebaiknya kita tunggu.

\section{Referensi}

Basri, Chatib, "1997/1998 National Budget Contractive", Indonesia Economic Almanac 1996-1997, Jakarta, 1997. Subiantoro, Edi, The Draft State Budget 1998/1999: Neither an Engine of economic Growth nor a Means to Radistribute Income", Indonesia Economic Almanac 1998, Jakarta, 1998. 